\title{
A social support for housewives with HIV/AIDS through a peer support group
}

\author{
Muchlis Achsan Udji Sofro, ${ }^{1}$ Ema Hidayanti ${ }^{2}$ \\ ${ }^{1}$ RSUP Dr. Kariadi Semarang/Faculty of Medicine, Universitas Diponegoro, ${ }^{2}$ Faculty of Da'wa and Communication \\ UIN Walisongo, Semarang - Indonesia
}

\begin{abstract}
Housewives with HIV/AIDS are faced with internal problems because the virus continues to invade their bodies and external problems such as caring for their husbands and children infected with HIV/AIDS, stigma and discrimination, maintaining family integrity and even taking responsibility for economic problems when the husband dies. They need social support. One of the most important sources of social support is peers, especially for those who have not done open status to the family. Peer support can be obtained through Peer Support Groups (KDS) through counseling, education, and information. This qualitative research using the methodology approach tries to explore the social support that is obtained by housewives with HIV/AIDS through peer support groups that they participate in General Hospital Dr. Kariadi Semarang. Research involving 15 informants shows that peer support groups can provide social support for them, including information support about the treatment and development of HIV/AIDS; emotional support, self-esteem support, and network support such as intensive communication and strong friendships; and real assistance: venture capital assistance, business skills, and assistance in accessing treatment.
\end{abstract}

Keywords: social support; housewife with HIV/AIDS; Peer Support Group

\begin{abstract}
Abstrak: Ibu rumah tangga penderita HIV/AIDS dihadapkan problem internal karena virus terus menyerang tubuhnya dan problem eksternal seperti merawat suami dan anak yang terinfeksi HIV/AIDS, stigma dan diskriminasi, mempertahankan keutuhan keluarga, bahkan bertanggung masalah ekonomi saat suami meninggal. Mereka membutuhkan dukungan sosial. Salah satu sumber dukungan sosial terpenting adalah teman sebaya, terutama bagi yang belum melakukan open status kepada keluarga. Dukungan sebaya dapat diperoleh melalui Kelompok Dukungan Sebaya (KDS) melalui konseling, edukasi, dan informasi. Penelitian kualitatif dengan pendekatan ednometodologi ini mencoba menggali dukungan sosial yang diperoleh ibu rumah tangga penderita HIV/AIDS melalui KDS yang mereka ikuti di RSUP. Dr. Kariadi Semarang. Penelitian yang melibatkan 15 informan ini menunjukkan bahwa kegiatan KDS mampu memberikan dukungan sosial bagi mereka antara lain dukungan informasi seputar pengobatan dan perkembangan penyakit HIV/AIDS; dukungan emosional, dukungan harga diri, dan dukungan jaringan seperti adanya komunikasi intensif dan persahabatan yang kuat; dan bantuan nyata: bantuan modal usaha, ketrampilan usaha, dan pendampingan akses pengobatan.
\end{abstract}

Kata Kunci: dukungan sosial: Ibu rumah tangga penderita HIV/AIDS; Kelompok Dukungan Sebaya

Corresponding Author: Muchlis Achsan Udji Sofro (e-mail: muchlis.aus@gmail.com). The Chief of Medical Staff Group. Internal Medicine of RSUP DR. Kariadi Faculty of Medicine Universitas Diponegoro, Jl. Soetomo 16 Semarang, Indonesia 50244. 


\section{Introduction}

The cases of HIV/AIDS continue to grow every year starting from the age of children to adults, especially housewives, based on data released by several mass media both print and online. Ramadhan (2013) asserts that the transmission of HIV/AIDS in Indonesia has recently begun to shift from vulnerable groups to low-risk groups, such as housewives and infants. The new cases of HIV/AIDS have emerged in a number of regions in Indonesia, such as in Bandar Lampung from a total of 198 new cases of HIV/AIDS, 84 cases (40\%) came from the group of housewives. Similar findings also occurred in Madiun, East Java and Cirebon, West Java. The high rate of HIV/AIDS among housewives was also confirmed by the Indonesian Minister of Health Nila F. Moeloek on the 1st AIDS Day commemoration on December 1st, 2016, that housewives were the highest population with HIV/AIDS with a total of 10,627 people, far adrift of sex workers which amounted to 2578 people and school children/students around 1764 people (Indriani \& Nodia, 2016).

The high rate of HIV/AIDS among housewives still persists from 2011-2018. As reported by P2P Directorate general at the Ministry of Health of the Republic of Indonesia in 2018 that the number of HIV/AIDS by occupation/status shows that housewives are ranked first then it is followed by second rank non-professional staff (employees). Based on the report, the real data collected from 1987-2018 showed the number of housewives 15,410 people and the number of nonprofessional workers 15,026 people (Dirjen Pengendalian dan Pengendalian Penyakit Kemenkes RI, 2018). The housewife was infected from the behavior of her husband who liked to buy sex. This was conveyed by the Executive Director of the Semarang Institute for Economic
Empowerment (LPSEK) Empowerment, that the population of male sex buyers was more than female commercial sex workers. Further confirmed data from the Sunan Kuning Semarang localization, there are 485 commercial sex workers (PSK), and on average there are 2,700 male sex buyers each month. Whereas from the number of male sex buyers, some of them married 1,300 women (Catur, 2018).

Udobong (2015) stated that a woman with HIV was usually a member of a family infected with HIV/AIDS. Usually she has one or more children who have been infected vertically. The woman (mother) was often the primary caregiver for sick family members, even though she also suffers from HIV disease. Individuals infected with HIV/AIDS are basically not merely human beings as individual creatures, but they are also social creatures that are part of the family and community (Hawari, 2010). This awareness must be built in dealing with HIV/AIDS so that individuals who have been infected do not transmit to other family members or others around them. In addition, individuals will get the social support needed while living their lives as PLHA (People Living with HIV/AIDS).

The social support is needed by PLWHA, because HIV/AIDS is a psychosocial stressor that gives negative effects to sufferers. According to Deekshitulu (2015) the psychosocial stressor is related to 3 main problems namely psychological, behavioral, and medical. Psychologically, PLWHA are faced with death, impatience in facing chronic pain, stress throughout life, depression, insecurity, lack or inability to receive emotional support, and poor coping. Behaviorally there are changes in breathing, dehydration, appetite, and unhealthy sleep patterns. While the situation is followed medically associated infections, limitations in accessing health services when sick, delay in 
understanding health problems related to illness, and low patterns of communication with health care providers. In addition, they experience social problems such as extreme stigma and discrimination (Sofro \& Sujatmoko, 2015). These psychosocial factors are very burdensome to PLWHA and can worsen their immune function, which when not handled properly.

PLWHA who are faced with these problems need social support. Social support itself is the belief that someone is loved, respected, and valued by and involved with family, friends, and others (Jia et al., 2004). Some researchers showed that social support for PLWHA directly affects health outcomes, it can be in the form of direct effects such as medication adherence (Husna, 2013), and quality of life (Diatmi \& Fridari, 2014). Meanwhile, according to notes Jia et al. (2004) various researches on social support for PLWHA showed significant results related to quality of life, psychological well-being of patients, depression, coping strategies for stress, and mental health. This showed that social support had a very significant impact on the survival of PLWHA themselves. Therefore, social support for PLWHA must be formed primarily from spouses, parents, children, friends, counselors, and health care providers.

Unfortunately, so far the expected social support has rarely been obtained by PLWHA including from their own families. Miller, Goldman, and Bor (1994) stated that the spread of HIV/AIDS has led to a redefinition of family meaning. The family is interpreted not only as blood relations, but also social relationships and even gender equality. Departing from this understanding, families for HIV/AIDS patients are not only those who have blood relations, but also those who have social relationships as fellow sufferers. Therefore, to facilitate the support of these peers, usually hospitals that become a referral center for PLWHA, form Peer Support Groups.

Peer Support Groups (PSG) is a national program that was initiated in 1995 by the National AIDS Eradication Commission (KPAN) in collaboration with the National Spiritia NGO (Komisi Pemberantasan AIDS Nasional, 2011). PSG is a container that provides a safe and comfortable environment for PLWHA. The peer support group functions as a place to exchange information and experience in solving problems faced by PLWHA (Ditjen Pemasyarakatan Kemenkumham RI, 2011). The significance of PSG for PLWHA is proven, among others, by Mardhiati and Handayani (2012) which shows that PLWHA who get peer support has a 7 times higher quality of life than those who do not get peer support. The quality of life of PLHWHA in question is an increase in self-confidence, better knowledge about the disease, have a lot of access to the availability of support services, treatment and care, have a risk-free behavior for HIV transmission and have many positive activities.

The other research conducted by Hidayanti, Hikmah, Wihartati, Handayani (2016) showed that PSG provided education and information through group guidance, and peer counseling. It could provide knowledge, share experiences, and help others solve problems. Such activities were ultimately able to foster self-esteem of terminal illness patients (HIV/AIDS) in RSUP Dr. Kariadi Semarang. Self-esteem itself was one form of social support felt by HIV/AIDS patients. The existence of PSG with various activities in general plays an important role in providing various forms of social support needed by PLWHA, whether it is information support, motivational support, or instrumental support.

Housewives are a group of patients classified as actively involved in PSG activities. For several 
times, the observations of PSG activities did show that participants were dominated by patients from housewives. This was confirmed by the PSG secretary of the RSUP Dr. Kariadi said that HIV/AIDS patients were dominated by housewives, and they actively participated in PGS. The reasons for active participation in PGS arose from the recognition of some patients themselves, among others, to get information about HIV/AIDS, to meet friends to be more enthusiastic and entertainment (Interview, 2018). Some of these active patients were housewives who had left their husbands. They generally sold something in order to make ends meet while at the same time paying for their children's needs. One of reasons that also arises is that they have not been widely open to their HIV status, so automatically the family has not provided social support. The solution was that they actively participate in PSG to get the social support needed from fellow PLWHA (Interview, 2018).

The characteristics of housewives with HIV/AIDS are interesting to study. This research tried to explore "How social support was felt by housewives with HIV/AIDS through peer support group forums at RSUP DR. Kariadi?" This research took place in Dr. RSUP Kariadi Semarang as one of the "PLWHA" referral hospitals in Central Java in accordance with the Republic of Indonesia Decree No. 832/Menkes/SK/X/2006. RSUP Dr. Kariadi already has a PSG which is part of health services for HIV/AIDS patients. This peer group group was one step ahead of other peer support groups. Beside from being a partner for referral hospitals that did not have peer support groups. RSUP Dr. Kariadi developed PSG which was an "open meeting", not a "close meeting" like PSG in general. This PSG received direct recognition as the best and most active PSG by the Chairman of the Central Java KPA in 2016. The PSG RSUD Dr.
Kariadi conducted formal meetings every once a month, namely on the 15 th. Activities undertaken included CIE (Counseling, Information, and Education) involving external speakers (doctors, religionist, and psychologists), students, HIV/ AIDS observers, besides PSG members themselves, there were PLWHA and their families. Non-formal activities were in the form of peer assistance to patients in need.

\section{Method}

This type of research was a qualitative descriptive study. It was Included as qualitative research because it aimed to answer research questions through formal and argumentative ways of thinking (Azwar, 2014). It was called descriptive because this study sought to provide solutions to existing problems based on data. So, besides presenting data, it also analyzes and interprets, and it could also be comparative and correlative (Narbuko \& Achmadi, 2005). This research was a descriptive qualitative research that was correlative in nature, which meant that it tried to describe the efforts to form social support for PLWHA through the peer support group Dr. Kariadi.

The research approach used ethnomethodology, which was an approach that referred to the problematic areas of concern, namely about individuals creating and understanding everyday life. Ethnometodology approaches tended to focus on micro problems and researchers were like "photographers" (Suyanto \& Sutiyah, 2005). With a qualitative ethnomethodology, this study tried to portray the role of peer support groups in shaping social support for housewives with HIV/AIDS RSUP Dr. Kariadi.

The research data were obtained through interviews and in-depth interviews with primary sources, namely housewives with HIV/AIDS, peer 
companions and administrators of The PSG RSUP Dr. Kariadi. The research involved 15 housewifeinformants consisting of 13 informants infected from husbands (sex buyers), 2 informants from husbands (ex-drugs), and 1 informant infected due to risky behavior (tattoo needles). Retrieval of informants using snowball sampling was based on the recommendations of the PSG board of RSUP Dr. Kariadi. Beside the interview, the data were obtained through observation of peer support groups and documentation in the form of notes about peer group activities. While the data analysis followed the Miles and Huberman analysis model which consisted of data reduction, data display, and conclusion drawing or verification (Sugiyono, 2007).

\section{Results}

The Peer Support Group RSUP Dr. Kariadi was formed in September 2005. The PSG RSUP Dr. Kariadi took the form of a monthly meeting every 15th, gathering all PLWHA taking antiretroviral (ARV) drugs. The PSG activity took place in the 3rd floor outpatient hall of Dr. RSUP Kariadi. The PSG was a meeting between PLWHA and service providers (doctors, nurses, pharmacists) to listen to complaints about services to improve the quality of services to PLWHA. The educational activity was arranged by a "close meeting" (a special meeting among PLWHA), namely sharing experiences and learning from each other in facing difficult times with HIV/AIDS and the problems that followed those illness (The PSG Documentation of RSUP Dr. Kariadi, 2016).

Since 2010, the PSG RSUP Dr. Kariadi cooperated with the Social Service Office of Central Java Province routinely provided financial assistance for monthly PSG meetings every February. The other collaboration was with the Semarang City AIDS Commission (KPA) and
Central Java Province KPA provided material at the PSG meeting. While with the Indonesian Ministry of Social Affairs, the cooperation was carried out incidentally in the form of venture capital which was allocated to 10 PLWHA, each of whom got a business capital of 5 million rupiah. Actually, the main activity of the PSG RSUP Dr. Kariadi was education and information in the form of providing material with the aim of increasing knowledge, attitudes, and healthy living behaviors for PLWHA. The material was presented by speakers from RSUP Dr. Kariadi alternately from functional medical staff for Internal Medicine, Children, Surgery, Obstetrics and Gynecology, Neurological Disease, Mental Illness, and Forensics. The PSG RSUP Dr. Kariadi also received a motivational contribution from the Healthy Living Spirit of the Faculty of Psychology at Sugiyopranoto University who invited PLHA to stay healthy and enthusiastic (The PSG Documentation, 2016).

The PSG Forum sought to provide skills by collaborating with the Budi Sehat Foundation in the form of a snack making skills course. It aimed to increase the knowledge and skills of PLWHA and was useful for earning income by making snacks that could be marketed in their neighborhood. The Outdoor activities were also carried out by holding picnic activities every two years. The intended recreation areas included Kampoeng Laut, Bandungan, Yogyakarta, and other tourist attractions. The purpose of this activity was to increase familiarity among PLWHA. Annual activities were held Halāl bi Halāl (Moslem Event) in every Shawwal month. The other most important activity was to record PLWHA who dropped out of drugs and lost to follow up. The PSG team then made a home visit to look for information on the reasons for not continuing treatment, as well as PLWHA given motivation to 
routinely go back to RSUP Dr. Kariadi Semarang (The PSG Documentation, 2016).

Thus, a brief description of the activities was organized by The PSG RSUP Dr. Kariadi. The benefits of PSG were felt by the participants. The housewives were participants who were quite dominating at each meeting. The perceived benefits were closely related to the social support needed by PLWHA including housewives who had partly lived as single parents because their husbands had died due to HIV/AIDS. The social support felt by housewives with HIV/AIDS was broken down into five aspects, namely information support, emotional support, and selfesteem support, network support and tangible assistance. This aspect followed the opinions (Coursaris \& Liu, 2009) which outlines five aspects of social support that could be provided in a support group for PLWHA. As clearly, the five aspects of social support felt by housewives with HIV/AIDS could be presented as follows:

\section{Information Support}

Information support here was intended to what extent PLWHA gaining knowledge and understanding of HIV/AIDS. This support could be observed in four ways namely (1) advice, (2) referral to experts, and resources, (3) situation assessment, and (4) teaching. This kind of support was clearly found by HIV/AIDS patients who took part in the PGS because at each meeting routine materials were provided relating to the treatment and development of HIV/AIDS. At several PGS meetings, for example, HIV/AIDs patients were presented with the following themes: Internal Network of TB DOTS and HIV TB by Dr. Nur Fahanah, Msi.Med, Sp.PD, K-PTI, Hearing loss in HIV patients delivered by Dr. Legawati Siringo Ringo Sp.THT, Healthy living with HIV by DR. Dr. Muchlis Achsan Udji Sofro Sp.PD KPTI (The PSG Document 2017).
The education and information activities were carried out not only in routine monthly meetings as above, but also in the form of workshops. One of the activities undertaken was the Short Training/Workshop for Non-ART PLWHA to Enhance Retention on May 22 2018. The activity had the aim of increasing knowledge to PLWHA about HIV, both related to ARV therapy, opportunistic infections, and so on, providing understanding the importance of ARV compliance, sharing experiences among PLWHA to increase compliance and motivating each other (The PSG Document 2018). According to the PSG secretary, the presented material was tailored to the needs of HIV/AIDS patients. This was because each patient often conveyed a problem faced either related to the effects of ARV therapy, or other problems that were still related to the disease they were suffering from (Interview, 12 November 2018).

The information delivered directly by the experts certainly provided many benefits for patients who routinely attended the PSG. As confession of patient $\mathrm{X}$, a housewife who contracted from her husband who had now died. Patient $\mathrm{X}$ said as the following:

“... ketahuan terinfeksi setelah suami meninggal, sejak itu saya ikut terus KDS...jadi banyak tahu HIV/AIDS itu apa, ... gak perlu nyari-nyari sendiri gak sempat Mbak... makanya rajin saja datang sekalian ketemu sama teman-teman" (... knew being infected after my husband died, since that moment then I joined along with the PSG ... so many (people) knew what HIV/AIDS was, .... didn't need to look for yourself, no time miss, so just diligently came and met with friends" (Interview, 12th November 2018).

Beside the patients felt the benefits of getting information about their illness, on the PSG forum, the patients could ask directly about the complaints they faced. For example, it was experienced 
by patient $\mathrm{B}$. This patient had complaints on the fingers that felt stiff when moved. At the forum, the patient $B$ had the opportunity to ask questions and sought advice from the doctor who was presenting the material. The Patient B told of her experience:

"kalau datang KDS bisa banyak dapat ilmu baru... materinya kan ganti-ganti, jadi tahu ini itu... dokternya juga enak kalau ditanya, soale aku pernah konsultasi keluhan tanganku yang waktu itu kaku gak seperti biasanya... terus dokter bilang... priksa saja di klinik infeksi seperti biasa, nanti bilang keluhan nanti dirujuk ke poli saraf... doktere jelasin banyak Mbak" (If (I) came the PSG, ... could get a lot of new knowledge ... the material changes so (I) knew this ... the doctor was also good when asked, cause I have consulted my hand complaints which were stiff, at the time not as usual ... then the doctor said ... just check in the infectious clinic like usual, later say complaints... will later be referred to nerve poly ... doctor explained a lot miss) (Interview, 15th November 2018).

The experiences of the two patients show that they obtained information related to HIV/AIDS. At the forum, the experts were also invited to provide direct education about the problems of HIV/AIDS patients and to provide advice for patients who asked questions and had complaints. This meant that patients got information support in the form of information from direct experts, advice, and the existence of education or teaching about new things needed in dealing with HIV/AIDS they suffered.

\section{Emotional Support}

Emotional support could be seen from several things, namely relationships, affection, confidentiality, sympathy, understanding, encouragement, and prayer (Coursaris \& Liu, 2009). The emotional support was needed by HIV/AIDS patients, especially in the early stages of infection. Moreover, for those who have not been able to open status with their closest spouse or family. The HIV/AIDS patients with this condition were highly recommended by officers at infectious disease clinics to join peer support groups. The aim was to help them adapt to the initial conditions after being infected and more importantly feel not alone in facing the disease (Interview, 15th November 2018).

Patient $\mathrm{T}$, a housewife, said that she was very shocked when she was sentenced to HIV/AIDS. Especially at that time, the patient $\mathrm{T}$ still experienced the grief of the departure of her husband who died of HIV/AIDS. The Patient T said how destroyed her life at that time, even had time to cry hysterically because they could not accept the reality. The following is a brief expression of patient $\mathrm{T}$ :

"awal ikut KDS disarankan oleh Mbak Wati, akhirnya aku datang. Pengalaman awal aku ketemu sama teman-teman di sini nangis histeris. Masih ingat aku dirangkul sama Mbak Nita dan Pak Wid (Pendamping dari LSM yang ikut KDS). Orang-orang itu yang nguatin aku waktu itu Mbak.... rasane aku kan belum bisa nerima, menikah sudah di usia sekian, malah suami meninggal dan nularin penyakit... siapa orang yang mau?" (at the beginning, (I was) advised to join the PSG by Ms. Wati, finally I came. My initial experience was that (I didn't want to share) with friends here crying hysterically. Still remember, I was embraced by Ms. Nita and Mr. Wid (the companion of NGOs who participated in the PSG). Those people who strengthened me at that time miss ... I was not able to accept it, I was already married at such an age, even my husband died and contracted the disease ... who would want to? (Interview, 15th November 2018).

Patient $T$ stated that joining the PSG provided many benefits especially when she felt strength with friends. Ms Nita and Mr Widodo at that time gave love and strength that made $\mathrm{T}$ study hard to accept reality. Moreover, the patient $\mathrm{T}$ had told that she received an extraordinary rejection from the family. However, the patient $\mathrm{T}$ was still 
grateful that her first brother and wife still care about her who had the status of PLWHA.

A rejection from families experienced by the patients was one of the reasons they needed to join the PSG. In addition, there was indeed a difficult situation faced by the patients, namely the unpreparedness of open status with the family. This kind of thing made them had no place to tell the problem at hand. Joining the PSG was a solution that could be taken by the patients, because there, they could share information and experiences facing difficult times living with HIV/AIDS. This was confirmed by one of the following peer companions:

"banyak dari kita yang tidak terbuka dengan keluarga, jadi otomatis kadang bingung mau cerita ini itu dengan siapa..., di sini mereka bisa berbagi tanpa harus takut rahasianya diketahui yang lain,....kalau sudah begini cerita ketemu teman ibaratnya eluh gimana, aku gimana bisa tukar pengalaman...kalau sudah kan bisa lebih enteng bisa keluarin apa yang jadi uneg-uneg" (many of us were not open with family, so automatically sometimes confused about who this story should share with ..., here they could share without fearing the secret was known to the others, .... if it's like this, telling the story when meeting a friend, it was like what you were like, how could I exchange experience ... if could, it would be easier to be able to get out what was in mind) (Interview, 12th November 2018).

The explanation above shows that the members of the peer support group could interact well. This, of course, because showed sympathy and shared with each other as fellow sufferers of HIV/AIDS. The interaction also shows that confidentiality was very important for patients who were not ready to open the status. The peer support group also provided emotional support in the aspects of prayer. A pray was an important part for the patients with HIV/AIDS in dealing with the disease. Various problems arose not only related to the physical effects of treatment but also the anxiety and boredom of undergoing lifelong ARV therapy.

One of peer companions explained that there was a point where the patients experienced stress, were bored, and were even reluctant to carry out routine treatment. The antiretroviral therapy that must be lived a lifetime by the patients was one of the reasons that encourage the emergence of such psychological problems. At each PSG meeting, the main task as a peer companion was to remind adherence to treatment and provide an explanation of the more complicated effects of stopping or not even taking ARV therapy. This issue was mandatory at the PSG forum. The companion also stressed that when accompanying the patient personally, he never forgot to advise the patients to always pray to overcome the boredom and anxiety of undergoing ARV therapy. According to the companion, praying was able to bring its own calm that was needed by the patients facing psychological dynamics that were not always in good condition, but also in bad conditions (Interview, 6th November 2018).

\section{Self-esteem Support}

Self-esteem support has three dimensions: First, praise, it means positive comments about the infection suffered. Second, validation means that it refers to a message stating agreement with the recipient's perspective about the person's situation, beliefs, actions, thoughts, or emotions. Third, eliminating mistakes, this support could be demonstrated by helping reduce feelings of guilty about HIV infection (Coursaris \& Liu, 2009). Support for self-esteem that covered these three dimensions was needed by HIV/AIDS patients without regard to the transmission factor. The point was that those who were infected due to risky behaviors such as free sex or injection needles, and those who were infected from a husband or blood transfusion. Patients with 
diverse sources of transmission still needed a support for self-esteem for survival.

For example, the housewife-patients who were generally infected from their husband who have changed partners or had a history of ex-drug addicts certainly needed a dimension of praise and validation. This means that they needed reinforcement of their position as victims, and praise that was able to strengthen to continue to survive. This was important to do especially not a few of those who have to survive for their children after the death of a husband who died of HIV/AIDS. As a direct statement from one of the following fortythree years old housewife:

"Alhamdulillah sehat terus mbak...walau suami sudah tidak ada dan ninggalin tiga anak saya masih bisa jualan buat anak-anak sekolah.... tanggung jawab saya sebagai ibu... kasihan to kalau anak-anak sampai tidak sekolah karena gak ada bapaknya, lha kok nyatanya di sini yang nasibe kayak saya ini yo banyak mbak" (Alhamdulillah, keep on being healthy, miss ... even though my husband was gone and left three children, I can still sell (Something) to (pay bill) for children's school .... my responsibility as a mother ... sorry for if the children did not go to school because did not have father, in fact apparently many of them have the same fate as me). (Interview, 12th November 2018).

The same thing was said by $\mathrm{W}$, a housewife patient who contracted from her husband as a parking attendant. This fortytwo years old woman revealed that:

"suami masih ada mbak...tapi kan ngasih jatahnya seadanya, tidak mesti, jadi aku ya usaha sedikit-dikit...jualan jajanan anak-anak di rumah. Dulu sich adekku banyak bantu setelah tahu aku kena begini sudah jauhin, gak mau lagi bantu-bantu kayak dulu.... seneng kalau datang begini bisa buat hiburan habis itu semangat jualan lagi cari rejeki nyambung hidup" (My husband still (lived) ... but gave me a modest ration, it doesn't have to be, so I should have a little business ... selling kids snacks at home. In the past, my brother helped me a lot, after knew I had this (dieses) like this, (he) didn't want to help anymore like (he) used to be... happy if (I) came this (event), it could be for entertainment, after that have the spirit of selling again, looking for a fortune to make a living" (Interview, 15th November 2018).

The experience of the two housewife patients above to continue to survive and struggle for life is inseparable from the role of one of the peer companions who have the same fate. Just call $\mathrm{N}$, is one of the peer companions who contracted from her ex-drug addict husband. Each opening of the PSG meeting begins with the opening of one of the peer assistants. At the opening, there was usually a session where the companion started giving introductory material or sharing personal experiences. As peer companion, $\mathrm{N}$ had many opportunities to share her experiences with participants about her life journey accompanying her husband who was already severely ill due to HIV/AIDS. On the other hand, $\mathrm{N}$ was also selfinfected due to contracting from her husband. Such conditions made N struggle hard to motivate a husband whose condition was getting worse and infused with feelings of guilt (The PSG Observation, 2017).

The Struggle of N accompanying her husband gave the expected results. The husband could gradually get healthy and recover. The husband could finally work again. N, who initially worked as a substitute for the husband's position to make a living during a husband's illness, was now still maintaining her job by continuing to carry out her main task of raising his two children. N's experience as a peer companion provided validation as well as fostering praise among patients with housewives in the same boat. In fact, $\mathrm{N}$ always stressed that although as victims the wives were actually strong and loyal, even motivating their husbands to be obedient to seek treatment, live 
healthy, and continue to struggle for life (The PSG Observation, 2017).

Meanwhile, the patients infected with HIV/AIDS due to their own behavior tended to need encouragement to reduce guilt. As told by $\mathrm{L}$, a young mother aged 25 years who was infected by a tattoo needle. She admitted in her body many tattoos were made when graduating from high school. The expression of regret was conveyed by this young mother; however, she felt greatly helped by a peer companion who accompanied her in the early stages of infection. This peer companion provided reinforcement to reduce guilt and sin due to her past actions (Interview, 6th November, 2018).

The PSG meeting, according to chairman Dr. Muchlish AU Safro S.Pd., KTPI tried to give encouragement for risky behaviors to break their habits and live healthy after being infected with HIV/AIDS. He emphasized:

"Kami mengajak mereka untuk meninggalkan kebiasaannya dan mulai kembali pada agama. Setidaknya untuk mengurangi kebiasaan buruk yang biasa mereka lakukan. Kami tidak menyalahkan toh mereka sudah tahu bahwa yang dilakukan adalah perbuatan yang dilarang agama. Jadi kami dorong pasien untuk makin dekat dengan agama, yang Islam mulai salatnya, yang Kristen rajinlah ke gereja, aja nyalah-salahke tapi diilengke" (We invited them to renounce their habits and began to return to the religion. At least, to reduce the bad habits they usually did. We did not blame them any way, they already knew that what was done was prohibited by the religion. So, we encouraged the patients to get closer to the religion, a moslem should please to pray, Christians should please more diligent in going to church, didn't blame it, but got rid of it" (Interview, 11th August 2018).

The PSG chairman's statement showed that there was always an effort being made in the PSG forum to help eradicate the guilt feelings of the patients who were infected due to their own behavior. Such enthusiasm was always apparent in every PSG session held every month. This is demonstrated by the commitment of the chairperson of the PSG, peer companion, and counselor to remind all patients to draw closer to God, to behave healthy even if infected. The third aspect, namely the elimination of guilt, complements the self-esteem support that could be played by the PSG, as well as two other aspects, namely praise and validation.

\section{Network Support}

This support could be seen from three things namely access, presence, and friendship. The access was realized by having the opportunity to get acquainted and add new friends to fellow PLWHA. Network support in the form of clear access could be obtained by HIV/AIDS patients through the PSG forum. This could be seen from the efforts to provide broad access for the patients to join the PSG RSUP Dr. Kariadi. Every new HIV/AIDS patient would be given access to join the PSG so they could meet fellow PLWHA. At the forum automatically, the HIV/AIDS patients get to know each other with peer companions, and other HIV/AIDS patients who took part in PSG. The existence of such an atmosphere, automatically deliver HIV/AIDS patients who were present at peer support activities to access new friends, namely fellow PLWHA who were considered suitable.

The organizer of the PSG of RSUP Dr. Kariadi also gave access to the HIV/AIDS patients to join the PSG who were closer to where they lived. This was because the HIV/AIDS patients seeking treatment at Dr. Kariadi Hospital were not all domiciled in Semarang. Even the HIV/AIDS patients came from many districts/cities in Central Java (The PSG Documentation, 2018). The opportunity for the HIV/AIDS patients after being able to access new friends could give birth to what was called attendance as part of this network support. The attendance was associated with 
having a person or group present who was a good listener for the HIV/AIDS patients. This kind of thing if traced further because they established communication outside the PSG meeting via mobile media, as one of the patients of a 51-yearold housewife admitted as an ex-migrant worker who contracted from her husband who was passed away. Just call the patient $P$ who said:

"dari awal ikut KDS sudah ketemu sama mbak $R$ (sesama ODHA berusia 32 tahun). Jadi sampai sekarang nek ada apa-apa saling ngasih tahu, saling cerita kan sama-sama janda ditinggal mati ditinggali anak (sambil senyum). Kadang juga janjian pas sama-sama waktunya ambil obat terus sekalian ikut pertemuan KDS. Karena sering bareng jadi $a k r a b$ mbak" (... from the beginning joined the PSG had met with Ms. R (fellow PLWHA aged 32 years). So, until now if there was anything to tell each other, tell each other stories, as the same status as widows left behind lived by children (while smiling). Sometimes the agreements were just the same when it's time to take medicine and all at the PSG meeting. Because (we) often get together, so (we) were close, sis"(Interview, 6th November 2018)

The recognition of the patients showed that there was access and presence which was the network support obtained through the PSG forum. In addition, the attendance aspect was seen in the cohesiveness of the mentors and several active PSG participants who were present expressed condolences for the death of the peer companion's husband. The presence of the PSG RSUP Dr. Kariadi accompanied a peer companion through a time of sorrow. Here also felt the aspect of friends in the network support. The friend aspect was very visible from the intimacy that was built by the peer companion with several other patients who were assisted. The task of peer companion usually accompanied the new patient in the early days until she could accept her condition, motivate the observance of treatment, and go to the place of pouring hearts. The existence of friendship among the PSG partici- pants was increasingly being felt by HIV/AIDS patients who had not yet opened status with their families (Interview, 2018).

\section{The Real Assistance}

The Support in this form, for example, could be seen from the existence of loans and helped the PLWHA task directly or indirectly. The loans could be in the form of money loans or goods needed by PLWHA. Here it helped with tasks related to the willingness to alleviate the responsibilities of PLWHA. The real assistance here could be compared with instrumental assistance, namely the provision of tools to help ease the burden borne by someone (Bukhori, Hassan, Hadjar, \& Hidayah, 2017). The instrumental assistance could be seen from the PSG collaboration with several institutions that were able to provide venture capital for the PSG participants. Although the intended capital was incidental because it depended on the party that channeled the capital, the real assistance could be felt directly by some active PSG participants. As stated at the beginning that the PSG Dr. Kariadi had received a capital injection for venture capital from the Ministry of Social Affairs of the Republic of Indonesia. The funds were intended for business capital of ten people living with HIV, who each got 5 million rupiah (The PSG Document, 2016).

In addition to the incidental assistance, there was transport money received by the HIV/AIDS patients at every PSG meeting that took place every month. The funds were varied, for example from the assistance of the Semarang City Social Office, the Care Foundation for Love, or the assistance from doctors at the RSUP Dr. Kariadi or other benefactors. Real assistance that was important for PLWHA was not only limited to the material as stated. The real assistance that almost all HIV/AIDS patients feel was the ease of getting ARV medicine. This could be seen from the full 
assistance given from the PSG management and accompanying efforts to ensure that the HIV/ AIDS patients' medinice were not late given and consumed (Observation, 2018).

The peer companions who had the responsibility of accompanying some PLWHA also had the responsibility to help them with monthly ARVs and distribute them directly to the PLHIVs they assist. The availability of ARV medicine that could be distributed by the peer companions certainly had a big hand from the PSG management to help access these medicines in the pharmacy department Dr. Kariadi. If the HIV/ AIDS patients could still take it themselves in the hospital, then they had been facilitated by taking ARV medicine directly to the infectious disease clinic, without having to queue long at the pharmacy Dr. Kariadi (Observation, 2018). Another tangible assistance was the assistance of treatment to the hospital. The peer companions were not only responsible for motivating adherence to patient treatment and ensuring they were on time to get and consume ARVs. The peer companion was also responsible for providing patient assistance if the course of his illness required intensive care. They helped their assisted HIV/AIDS patients to get treatment in accordance with the complaints experienced (Interview, 6th November 2018).

Based on the description above, it could be seen that the PSG Dr. Kariadi succeeded in carrying out its functions, including: a) helping PLWHA not feel isolated and alone in facing problems; b) paving the way to meet other PLWHA or other people who care; c) helping PLWHA become more confident and accept their HIV status; d) helping PLWHA to share information, for example about the treatment or support available to PLWHA; e) helping to expose HIV status to family or partner; f) giving new PLWHA knowledge about what happened in their bodies when they were infected with HIV and about the continuity of the infection; g) disseminating information about available treatments and how they could be obtained; and h) supporting adherence to antiretroviral therapy (ARV) and other treatments (Ditjen Pemasyarakatan Kemenkumham RI, 2011).

The success in carrying out these functions showed that the PSG RSUP. Dr. Kariadi has made efforts to shape the social support needed by PLWHA. The overall function was able to encourage the fulfillment of diverse social support, especially information support, emotional support, and network support. Besides being able to carry out these functions, the PSG RSUP Dr. Kariadi provided a variety of activities ranging from education, counseling, information, even to skills training for PLWHA. Group activities like the PSG were basically able to present a therapeutic impact that was very beneficial for its members. As mentioned by Priyanto (2009) the therapeutic impact of group activities included: a) Universality. The client realized that she was not the only one who had problems in her life; b) Input information. Feedback of Information about a person's behavior and its effect on group members; c) Instill the expectancy of life. Something that has been achieved was due to the role of the client who had advanced with the problem and also the emotional support of the group; d) Altruism. Occurred because the members provided a support for one another, not only accepting ideas but also contributing ideas; e) Development of social skills. The clients could get feedback and have the opportunity to learn and practice new ways of interacting; f) Catharsis and strong emotional division. This means that within the group not only helped to reduce emotional tension but also to reinforce feelings of closeness within group members.

Based on the above opinion, if explored further, it showed that the peer support group Dr. Kariadi had the intended therapeutic impact. 
Some impacts that were felt by PLWHA included universality, where every housewife with HIV/AIDS who joins PSG finds friends who were the same fate as them. It could be seen from the recognition of the $\mathrm{P}$ informant above who was close to R while attending the PSG, even the communication continued well outside the PSG forum (Interview, 6 November 2018). From the aspect of input information, it had become one of the main impacts because the PSG members were given education about various things related to HIV. As stated by informants X and B above, they felt they had gained deeper knowledge about HIV/AIDS because they actively participated in the PSG (Interview, 12th and 15th November 2018).

The therapeutic effect felt by housewives infected with HIV/AIDS in the PSG forum was the presence of catharsis among members. Moreover, the fellow housewives were a place where they could share and strengthen each other. This kind of experience was strongly felt by informants $\mathrm{T}$, as explained above. Self-employed catharsis was conducted by $\mathrm{T}$ informants to the peer companions in the early days, especially in building self-acceptance and readiness to open status to their families. Another important thing, this PSG forum could provide opportunities for housewives with HIV/AIDS to develop social skills, namely establishing good relationships with others and their environment after infection and learning from each other to face various problems. This was evident from the story told by W informants who felt they could share with others who were in the same boat with her. She must be independent by selling because her husband could not be relied on to provide for her children (Interview, 15th November 2018). Through the PSG forum, they could also learn from the peer companions as seen by $\mathrm{N}$ who tries to inspire friendly housewives with HIV/AIDS through telling their personal stories that were almost the same as them because they were infected by their husbands (Observation PSG, 2017).

The therapeutic impact felt by the housewives with HIV/AIDS showed that the PSG could be an effort to grow social support in various forms ranging from information support, emotional support, self-esteem support, network support, and real assistance. This social support gave importance to the journey of life of PLWHA such as supporting stress and increasing their sense of emotional well-being (Kalichman, DiMarco, Austin, Luke, \& DiFonzo, 2003). Social support was also found as one of the factors motivating the HIV/AIDS sufferers to undergo treatment compliance (Bachrun, 2017), making individuals more receptive to their status as PLWHA, more positive in facing life, and social support acts as a reinforcer and helper (Romadhani \& Sutarmanto, 2017). Even social support was related to quality of life, psychological well-being of patients, depression, stress coping strategies, and mental health (Jia et al., 2004).

The availability of social support gave PLWHA experience that they were loved, valued, and cared for. Attention and support from others could foster a hope to live longer, while reducing individual anxiety. Conversely, lack of social support made individuals felt worthless and isolated (Astuti \& Budiyani, 2012). This could be felt through emotional support and self-esteem support felt by the housewives with HIV/AIDS, as perceived by informant $\mathrm{W}$ through the above narrative. Informant $\mathrm{W}$ felt motivated when she met with her fellow women who was in the same situation and was eager to return to selling at home to raise children without relying on her husband who did not always provide for family income (Interview, 15 November 2018). Selfesteem support in the form of praise and 
reinforcement of the behavior of informants $\mathrm{W}$ and their peers carried out by the peer companions at the peer support groups in addressing HIV/AIDS infection, was actually almost similar to assessment support. As Bukhori (2012), revealed, assessment support included work support, achievement, and social roles consisting of feedback, comparison, and affirmations (approval states "Yes").

The support for self-esteem or assessment support felt by the housewives with HIV/AIDS was very much needed for PLWHA to be able to accept their condition and fight against their illness. This was felt by the informant $\mathrm{T}$, who finally slowly accepted himself infected with HIV/AIDS from a deceased husband from the peer companion at each PSG meeting. Selfacceptance eventually gave birth to self-esteem in the $\mathrm{T}$ informants by doing routine treatment. According to Mann, Hosman, Schaalma, and de Vries (2004), self-esteem was an important factor for individuals to protect themselves from stress, fear, uncertainty over physical pain, even avoiding depression, especially for those with chronic illness. In HIV/AIDS sufferers, also confirmed by Mann et al. (2004), citing some other research results that positive self-esteem could lead to protective behavior against contracting AIDS, while low self-esteem contributes for vulnerability to HIV/AIDS. In addition, it was also mentioned that positive self-esteem among gays could reduce them to engage in risky sexual behavior that opened wide opportunities for HIV/AIDS infection.

The other social support in the form of network support in which access, presence and friendship was provided. This support provided an opportunity for the housewives with the HIV/AIDS to meet with others, felt the meaning of the presence of one another so that they could foster friendship. This could be seen in the recognition of informant $\mathrm{P}$ who had closeness with patient $\mathrm{T}$, where their closeness was built because of their active participation in the PSG forum, and even continued outside the PSG forum through intensive communication via mobile phones (Interview, 8th November 2018). This network support was very closely related to emotional support in which there was empathy, a sense of togetherness, warmth, and attention (Bukhori et al., 2017). This social support gave meaning to PLHWA, including the ability to find meaning in life after being infected with HIV/AIDS. Some housewives who were infected with HIV/AIDS actually felt more able to feel the meaning of being infected with HIV/AIDS after they joined the PSG. Giving meaning to the life that humans live was closely related to the source of meaningfulness of life, namely values and attitudes towards tragic situations such as illness, suffering, and death. Bad situations that caused despair were precisely addressed so that they could flow blessings and valuable lessons that actually helped the process of maturity and contributed to the good in the future (Bukhori, 2012).

Finding the meaning of life could help the housewives take wisdom from being infected because of interactions with others in the PSG forum. The emotional support, the self-esteem support, and the network support became the bridge to achieving success in finding their life's prosperity. The happiness could finally be present and felt by the housewives who were infected with HIV/AIDS. Another important thing related to their happiness was the element of forgiveness. For example, it could be seen clearly in the $\mathrm{N}$ case, even though the husband is transmitting, but this one housewife actually gave enthusiasm and faithfully to accompany the husband who was already seriously ill. This forgiveness by $\mathrm{N}$ was very precise so that $\mathrm{N}$ was spared from negative effects that could worsen the situation (The 
Observation of The PSG Forum, 2017). According to Gani (2011, cited by Kusprayogi \& Nashori, 2016) if it did not forgive the impact of having symptoms of high blood pressure, stress, anger easily triggered, elevated heart pressure, showing symptoms of depression, showing symptoms of anxiety, feeling acute pain in the body, relationships with others less familiar, difficult to make friends, feel empty, and tendency to run away on alcoholic drinks and drugs.

The forgiveness that was done by $\mathrm{N}$ actually gave birth to self-acceptance of her husband and gave her strength to face being infected with HIV/AIDS. This experience seemed to be shared by $\mathrm{N}$ in the PSG forum, so that the housewives who had problems such as it, they could learn to build good relationships with their husbands again. transmitting HIV/AIDS from this case could finally build self-esteem support not only for $\mathrm{N}$ who received praise for her husband's treatment, but it also provided reinforcement or validation for other housewives to engage in such behavior for the husband who infected her. A good relationship with the husband was able to foster mutual support and be able to keep the family in harmony (Hidayanti et al., 2016).

The various form of social support obtained by the housewives with HIV/AIDS through the PSG forum proved to provide many positive benefits. For patients with HIV/AIDS as with other chronic diseases, the positive benefits included having the ability to cope with stress caused by the disease, developing a good attitude in life, making the best effort in the treatment of the disease and giving the right meaning to the reality of his current life (Taufiq, 2005) Those Attitudes will be easy to have when getting social support, one of them from peers. Although this disease is medically incurable, social support can help patients have psychological well-being, and mental health (Jia et al., 2004). Such conditions will make patients able to make good use of their lives, without regret, remain happy even if at the end the disease take the patient to die (Hidayanti et al., 2016).

\section{Conclusion}

Based on the discussion, it could be concluded that social support for the housewives with HIV/AIDS through the PSG Dr. Kariadi with giving counseling, information and education activities. The obtained forms of social support included information support in the form of discussions and workshops around the treatment and development of HIV/AIDS; emotional support such as compassion, mutual understanding, and maintaining confidentiality between them; self-esteem support in the form of praise, reinforcement and help eradicate guilt; network support, namely intensive communication and strong friendship between them, and tangible assistance in the form of venture capital assistance, business skills, and assistance in accessing treatment. The variety of social support was important for the housewives with HIV/AIDS to carry out their survival.

\section{Suggestion}

The results of this study could be used as a basis for developing research with similar themes both quantitatively and qualitatively. Quantitatively, it was developed by involving more respondents and knowing how far the role of the PSG contributed to social support for PLWHA. Qualitatively, similar research was developed further, especially for HIV/AIDS patients infected with HIV/AIDS due to risky behaviors such as MSM (Men Like Men), commercial sex workers (CSWs), Injecting Drug Use (IDU), and sex buyers. This would be empirical evidence of the importance of the role of the PSG for PLWHA and the need to optimize the role of PSG in every PLHWA referral hospital. The results of research on "Social support for PLWHA through the PSG" 
both quantitatively and qualitatively will be one way to see the achievement of the program "Sustainable Comprehensive HIV-STI Services" from the Ministry of Health in which emphasizes attention to the social aspects of the patients by involving family, the peer support groups, and community.[]

\section{References}

Astuti, A., \& Budiyani, K. (2012). Hubungan antara dukungan sosial yang diterima dengan kebermaknaan hidup pada ODHA (orang dengan HIV/AIDS). Jurnal Insight, 1-10.

Azwar, S. (2014). Metodologi penelitian. Yogyakarta: Pustaka Pelajar.

Bachrun, E. (2017). Hubungan dukungan keluarga dengan kepatuhan minum obat antiretroviral pada orang dengan HIV/AIDS (ODHA). 2-Trik: Tunas-Tunas Riset Kesehatan, 7(1), 57-61.

Bukhori, B. (2012). Hubungan kebermaknaan hidup dan dukungan sosial keluarga dengan kesehatan mental narapidana (Studi kasus nara pidana Kota Semarang). Ad-Din, 4(1), 1-19.

Bukhori, B., Hassan, Z., Hadjar, I., \& Hidayah, R. (2017). The effect of sprituality and social support from the family toward final semester university students' resilience. Man in India, 97(19), 313-321.

Catur, W. E. (2018). Kenapa ibu rumah tangga tertular HIV/AIDS, inilah penjelasannya. Retrieved from https://jateng.tribunnews.com/2018/11/28/kenapa-ibu-rumah-tangga-rawan-tertularhivaids-inilah-penjelasannya

Coursaris, C. K., \& Liu, M. (2009). An analysis of social support exchanges in online HIV/AIDS self-help groups. Computers in Human Behavior, 25(4), 911-918. https://doi.org/10.1016/ j.chb.2009.03.006

Deekshitulu, B. (2015). Stress aspects in HIV diseae. The International Journal of Indian Psychology, 3(SI), 75-80. Retrieved from http://oaji.net/articles/2015/1170-1448527010.pdf

Diatmi, K., \& Fridari, I. G. A. D. (2014). Hubungan antara dukungan sosial dengan kualitas hidup pada orang dengan HIV dan AIDS (ODHA) di Yayasan Spirit Paramacitta. Jurnal Psikologi Udayana, 1(2), 353-362. https://doi.org/10.24843/jpu.v1i2.25103

Dirjen Pengendalian dan Pengendalian Penyakit Kemenkes RI. (2018). Laporan perkembangan HIV/AIDS dan infeksi menular seksual triwulan II tahun 2018. Jakarta: Kementerian Kesehatan RI. Retrieved from siha.depkes.go.id

Ditjen Pemasyarakatan Kemenkumham RI. (2011). Buku saku dukungan sebaya di Lapas/Rutan. Jakarta: Kemenkumham RI.

Hawari, D. (2010). Al-Qur'an: Ilmu kedokteran jiwa dan kesehatan jiwa. Yogyakarta: Dana Bhakti Prima Yasa.

Hidayanti, E., Hikmah, S., Wihartati, W., \& Handayani, M. R. (2016). Kontribusi konseling Islam dalam mewujudkan palliative care bagi pasien HIV/AIDS di Rumah Sakit Islam Sultan Agung Semarang. Religia, 19(1), 113-132. https://doi.org/10.28918/religia.v19i1.662

Husna, C. (2013). Analisis dukungan sosial dengan kepatuhan therapy antiretroviral (ARV) pada pasien HIV/AIDS di Poliklinik Khusus RSUD. Dr. Zainoel Abidin Banda Aceh. Jurnal Ilmu Keperawatan, 1(1), 9-19. 
Indriani, R., \& Nodia, F. (2016). Menkes: Kasus HIV/AIDS tertinggi dialami ibu rumah tangga. Retrieved from https://www.suara.com/health/2016/12/01/160917/menkes-kasus-hiv-aids-tertinggidialami-ibu-rumah-tangga

Jia, H., Uphold, C. R., Wu, S., Reid, K., Findley, K., \& Duncan, P. W. (2004). Health-related quality of life among men with HIV infection: effects of social support, coping, and depression. AIDS Patient Care and STDs, 18(10), 594-603. https://doi.org/10.1089/apc.2004.18.594

Kalichman, S. C., DiMarco, M., Austin, J., Luke, W., \& DiFonzo, K. (2003). Stress, social support, and HIVstatus disclosure to family and friends among HIV-positive men and women. Journal of Behavioral Medicine, 26(4), 315-332. Retrieved from http://www.ncbi.nlm.nih.gov/ pubmed/12921006

Komisi Pemberantasan AIDS Nasional. (2011). Rangkuman Eksekutif Upaya Penanggulangan HIV dan AIDS di Indonesia 2006-2011. Jakarta: KPAN.

Kusprayogi, Y., \& Nashori, F. (2016). Kerendahhatian dan Pemaafan pada Mahasiswa. Psikohumaniora: Jurnal Penelitian Psikologi, 1(1), 12. https://doi.org/10.21580/pjpp.v1i1.963

Mann, M., Hosman, C. M. H., Schaalma, H. P., \& de Vries, N. K. (2004). Self-esteem in a broad-spectrum approach for mental health promotion. Health Education Research, 19(4), 357-372. https://doi.org/10.1093/her/cyg041

Mardhiati, R., \& Handayani, S. (2012). Peran dukungan sebaya dalam meningkatkan mutu hidup ODHA di Indonesia tahun 2011. Jakarta: Yayasan Spiritia.

Miller, R., Goldman, E., \& Bor, R. (1994). Application of a family systems approach to working with people affected by HIV disease - two case studies. Journal of Family Therapy, 16(3), 295-312. https://doi.org/10.1111/j.1467-6427.1994.00798.x

Narbuko, C., \& Achmadi, A. (2005). Metodologi penelitian. Jakarta: Bumi Aksara.

Priyanto, A. (2009). Komunikasi dan konseling aplikasi dalam pelayanan kesehatan. Jakarta: Salemba Medika.

Ramadhan, H. (2013). Tingginya angka HIV/ AIDS di kalangan ibu rumah tangga. Retrieved from https://www.jurnalperempuan.org/tingginya-angka-hivaids-dikalangan-ibu-rumahtangga.html

Romadhani, R. K., \& Sutarmanto, H. (2017). Dinamika dukungan sosial bagi orang dengan HIV/AIDS. Jurnal Penelitian Humaniora, 22(2), 99-110. https://doi.org/10.1258/ijsa.2008.008348

Sofro, M. A. U., \& Sujatmoko, S. A. (2015). Sehat dan sukses dengan HIV/AIDS. Jakarta: Elex Media Komputindo Gramedia.

Sugiyono. (2007). Metode penelitian pendidikan pendekatan kuantitatif, Kualitatif dan R\&D. Bandung: Alfabeta.

Suyanto, \& Sutiyah. (2005). Metodologi ilmu sosial. Yogyakarta: Pustaka Pelajar.

Taufiq, A. (2005). Konseling kelompok bagi individu berpenyakit kronis. In M. Supriatna \& A. J. Nurihsan (Eds.), Pendidikan dan konseling di era gobal dalam perspektif Prof. DR. M. Dahlan. Bandung: Rizki Press.

Udobong, R. (2015). Coping strategy of women with HIV-AIDS: Influence of care-giving, family social attitude, and effective communication. Science Journal of Public Health, 3(1), 107-113. https://doi.org/10.11648/j.sjph.20150301.29 
This page intentionally left blank. 